\title{
ВСЕСВІТНІЙ САМІТ МИРУ В СЕУЛІ 2020
}

\author{
2-8 лютого 2020 р., Сеул, Республіка Корея \\ https://doi.org/10.37472/2707-305X-2020-2-1-4-1
}

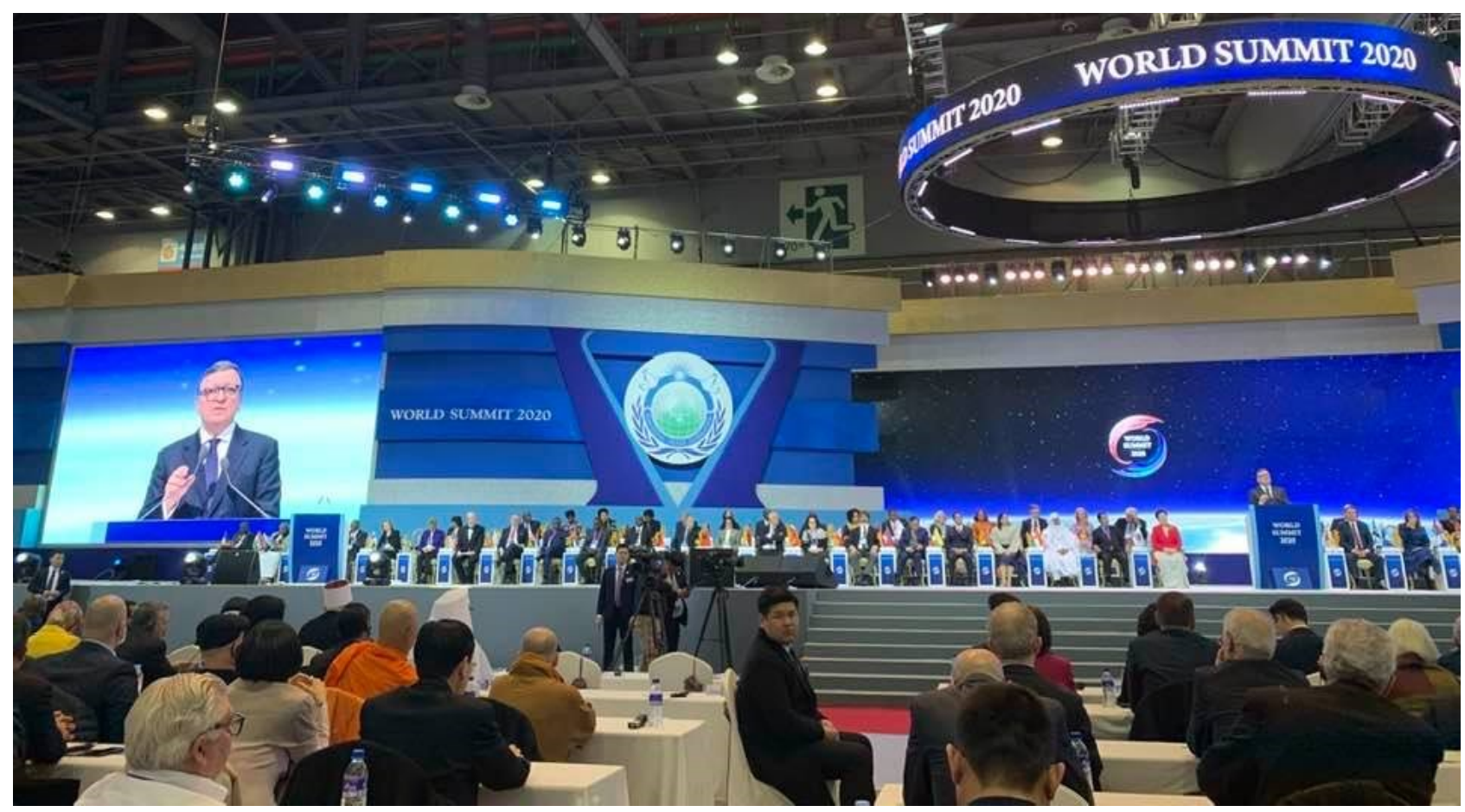

\section{КРЕМЕНЬ Василь Григорович}

доктор філософських наук, професор, дійсний член (академік) НАН України і НАПН України, президент Національної академії педагогічних наук України, м. Київ, Україна

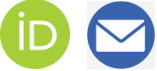

Анотація. 2-8 лютого 2020 р. відбувся World Summit 2020, в якому взяв участь президент НАПН України В.Г. Кремень. У рамках World Summit 2020 відбувся Всесвітній конгрес президентів університетів "The Реасе of Humankind and the Role of University in the Next 100 Years», на якому пріоритетними в обговоренні були питання щодо проведення університетами необхідних заходів для зміцнення миру. 3 доповіддю виступив В.Г. Кремень та звернув увагу на розвитку людського капіталу на основі дитиноцентризму в школі, студентоцентризму в університеті, а також розвитку людини з інноваційним мисленням і максимальним використанням цифрових технологій в освіті.

Ключові слова: дитиноцентризм; студентоцентризм; World Summit 2020; зміцнення миру.

На запрошення Всесвітньої федерації миру президент НАПН України В.Г. Кремень взяв участь у World Summit 2020 (2-8 лютого 2020 р.), що відбувся у Сеулі, та присвячений 100-річному ювілею з дня народження його засновника доктора Мун Сон Мьона. Ключовою метою створення та широкомасштабної діяльності World Summit визначено реалізацію ідеалу мирного світу у глобальному вимірі. Для цього необхідно мати майданчик для дискусії, де лідери та експерти (політики, фінансів, релігії, суспільства, культури та мистецтва) можуть працювати спільно для вирішення проблем міжнародних конфліктів. У 2020 р. головна тема World Summit полягала у «Реалізації світового миру та об'єднання Корейського півострова на базі взаємодопомоги, спільного процвітання та універсальних цінностей». На відкритті World Summit 2020 були присутні 5 тисяч громадян із понад 170 країн світу.

4 лютого 2020 р. у рамках World Summit 2020 відбувся Всесвітній конгрес президентів університетів «The Peace of Humankind and the Role of 
University in the Next 100 Years», на якому пріоритетними в обговоренні були питання щодо проведення університетами необхідних заходів для зміцнення миру. На конференції виступив В.Г. Кремень і наголосив на важливості збереження миру в умовах, коли людство набуло здатності до самознищення. Зокрема, звернуто увагу, що для України проблема миру особливо актуальна, з огляду на те, що шість років тому в результаті агресивної політики Росії анексовано Крим і розв'язано війну в Донбасі. Загинуло майже 14 тис. людей, 28 тис. поранено, 1,5 млн біженців, серед

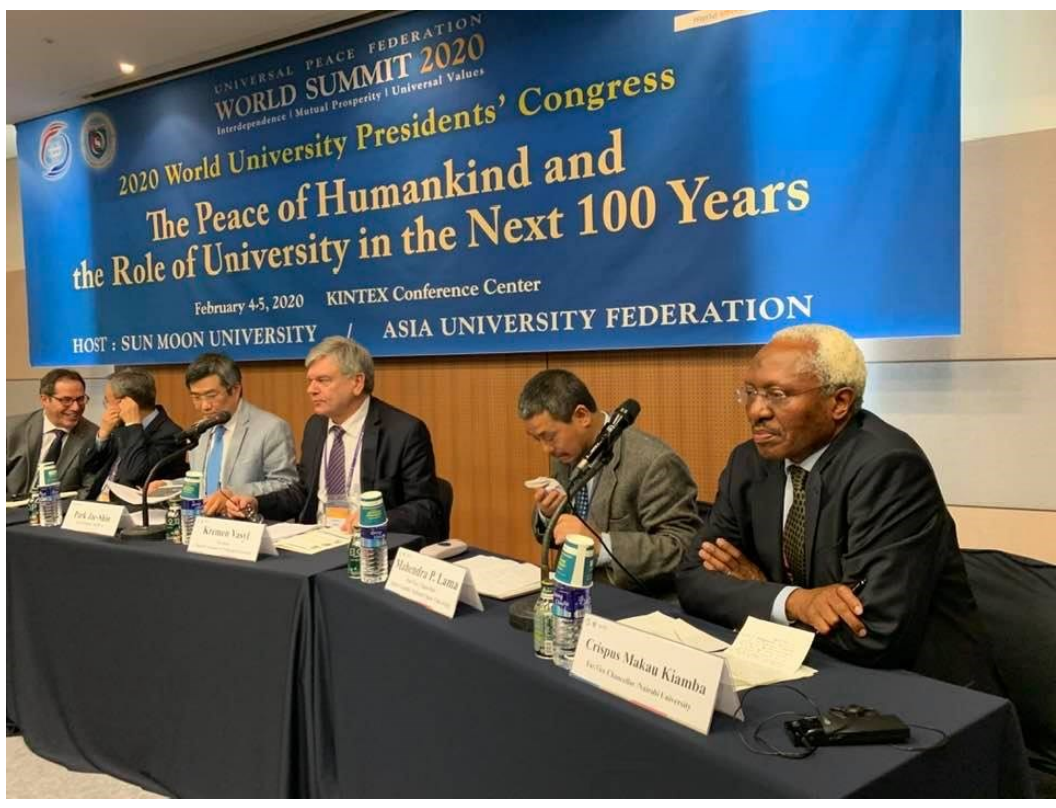
них багато дітей. Більше десяти університетів евакуйовано. В.Г. Кремень подякував країнам, що підтримують Україну в її намаганні зупинити війну і поновити територіальну цілісність, та висловив своє бачення щодо завдань університетів, 3поміж яких основоположними $є$ такі.

Передусім, рівень прогресивності будь-якої країни в сучасних умовах вимірюється рівнем розвитку людського капіталу, який відповідно визначає і подальший прогрес країни, бо саме від цього залежить розвиток науково-інформаційних технологій. Ураховуючи це, необхідно:

- по-перше, надати якісну освіту максимальній кількості молодих людей;

- по-друге, забезпечити інноваційний тип прогресу, коли в суспільстві відбувається швидка зміна ідей і знань. Тому слід готувати інноваційну людину - з інноваційним мисленням, інноваційною культурою і здатністю до інноваційного типу діяльності;

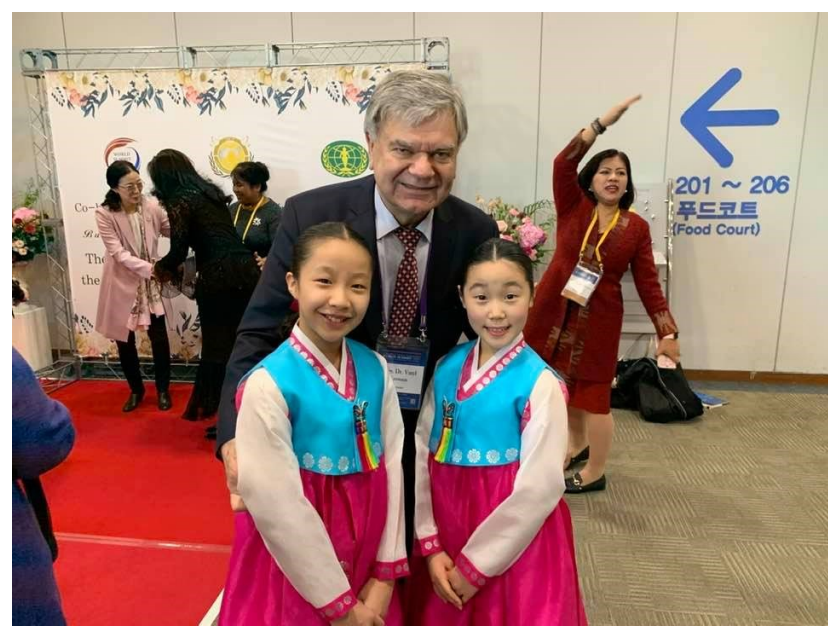

- по-третє, максимально використовувати цифрові технології в освіті, що зумовлено вимогами цифрового суспільства та підготовкою до життя в ньому;

- по-четверте, формувати не лише патріота своєї країни, а й людину глобалістську, що $\epsilon$ конкурентоспроможною в глобальному просторі і забезпечує так національну конкурентоспроможність;

- по-п'яте, формувати розвинену самодостатню особистість, яка б усвідомлено ставилась до зовнішнього впливу, була носієм демократичних і гуманних цінностей, оскільки сучасна людина знаходиться у все більш потужному інформаційно-комунікативному просторі, де зростають можливості різноманітного впливу на неї.

Провідною ідеєю в освіті, на думку В.Г.Кременя, повинен бути дитиноцентризм в школі, студентоцентризм - в університеті. Тобто максимальне врахування особистих здібностей та особливостей кожного учня і студента в його навчанні. Це неможливо без толерантної педагогіки, взаємного пошанування професора і студента. Дитиноцентризм в освіті відкриє шлях до утвердження людиноцентризму в суспільстві, де людина буде найвищою цінністю і кожен громадянин отримає найліпші умови для самопізнання, саморозвитку і самореалізації. А отже - для особистого щастя і забезпечення динамічного і несуперечливого розвитку своєї країни. Саме таке суспільство буде мирним і не створюватиме загрози для інших держав.

За матеріалами Педагогічної газети України, № 1 (275), січень-лютий 2020, с. 1. 


\section{WORLD SUMMIT 2020}

February 2-8, 2020, Seoul, Republic of Korea

\section{Vasyl Kremen}

DSc in Philosophy, Professor, Full Member (Academician) of NAS of Ukraine and NAES of Ukraine, President, National Academy of Educational Sciences of Ukraine, Kyiv, Ukraine

Abstract. The World Summit 2020 was February 2-8, 2020; the president of the National Academy of Educational Sciences of Ukraine Vasyl Kremen participated in it. During the Summit there was the 2020 World University Presidents' Congress "The Peace of Humankind and the Role of University in the Next 100 Years". Vasyl Kremen made a report and focused on the development of human capital on the basis of child-centrism in schools and student-centrism in universities, development of human with innovative thinking and maximum use of digital technologies in education.

Keywords: child-centered approach; student-centered approach; World Summit 2020; strengthening peace.

Дата публікації: 12 лютого 2020 р. 